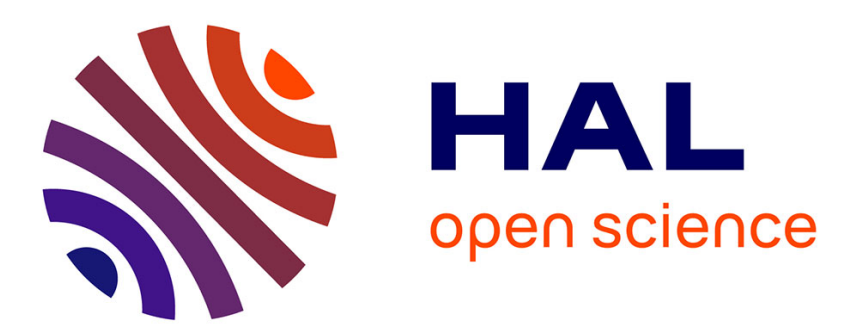

\title{
Validity domains and parametrizations for white-noise and multiscale models in turbulence and wave-turbulence interactions
}

\author{
Valentin Resseguier, E Hascoet, B Chapron, B Fox-Kemper
}

\section{To cite this version:}

Valentin Resseguier, E Hascoet, B Chapron, B Fox-Kemper. Validity domains and parametrizations for white-noise and multiscale models in turbulence and wave-turbulence interactions. European Geophysical Union (EGU) 2021, Apr 2021, video-conference, France. hal-03212231

\section{HAL Id: hal-03212231 \\ https://hal.science/hal-03212231}

Submitted on 29 Apr 2021

HAL is a multi-disciplinary open access archive for the deposit and dissemination of scientific research documents, whether they are published or not. The documents may come from teaching and research institutions in France or abroad, or from public or private research centers.
L'archive ouverte pluridisciplinaire HAL, est destinée au dépôt et à la diffusion de documents scientifiques de niveau recherche, publiés ou non, émanant des établissements d'enseignement et de recherche français ou étrangers, des laboratoires publics ou privés. 


\section{Validity domains and parametrizations for white-noise and multiscale models in turbulence and wave-turbulence interactions \\ V Resseguier, E Hascoet, B. Chapron, B. Fox-Kemper}

Validity of the time decorrelation assumption for $\boldsymbol{v}^{\prime}$ for turbulence / wave-turbulence:

$$
\frac{\left(\begin{array}{c}
\text { Along-flow/ray } \\
v^{\prime} \text { correlation time }
\end{array}\right)}{\left(\begin{array}{c}
\text { characteristic time of } \\
\text { flow/wave group } \\
\text { properties evolution }
\end{array}\right)}=\frac{\left(\frac{l_{v^{\prime}}}{\|v\| /\left\|C_{g}^{0}\right\|}\right)}{\left(\frac{1}{\|\nabla v\|}\right)} \ll 1
$$

\section{Applied to}

steep-spectrum (SQG) and flat-spectrum (2D Euler) dynamics; homogeneous and heterogeneous flows
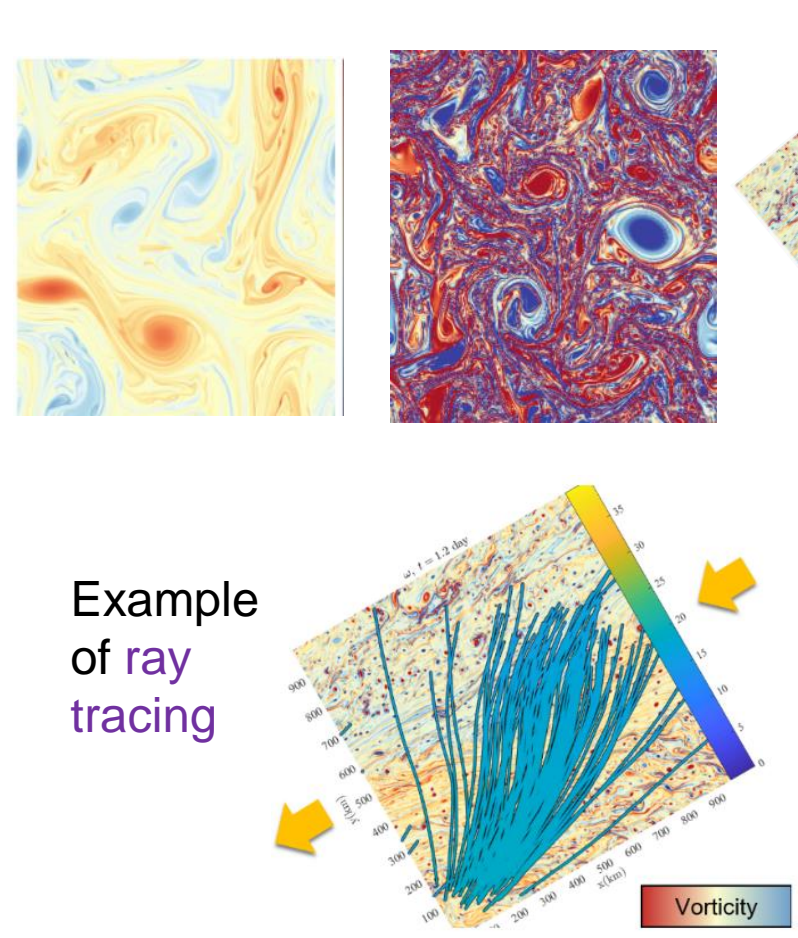
for data assimilation

\section{Parametrization of white $v^{\prime}$ for simulations}

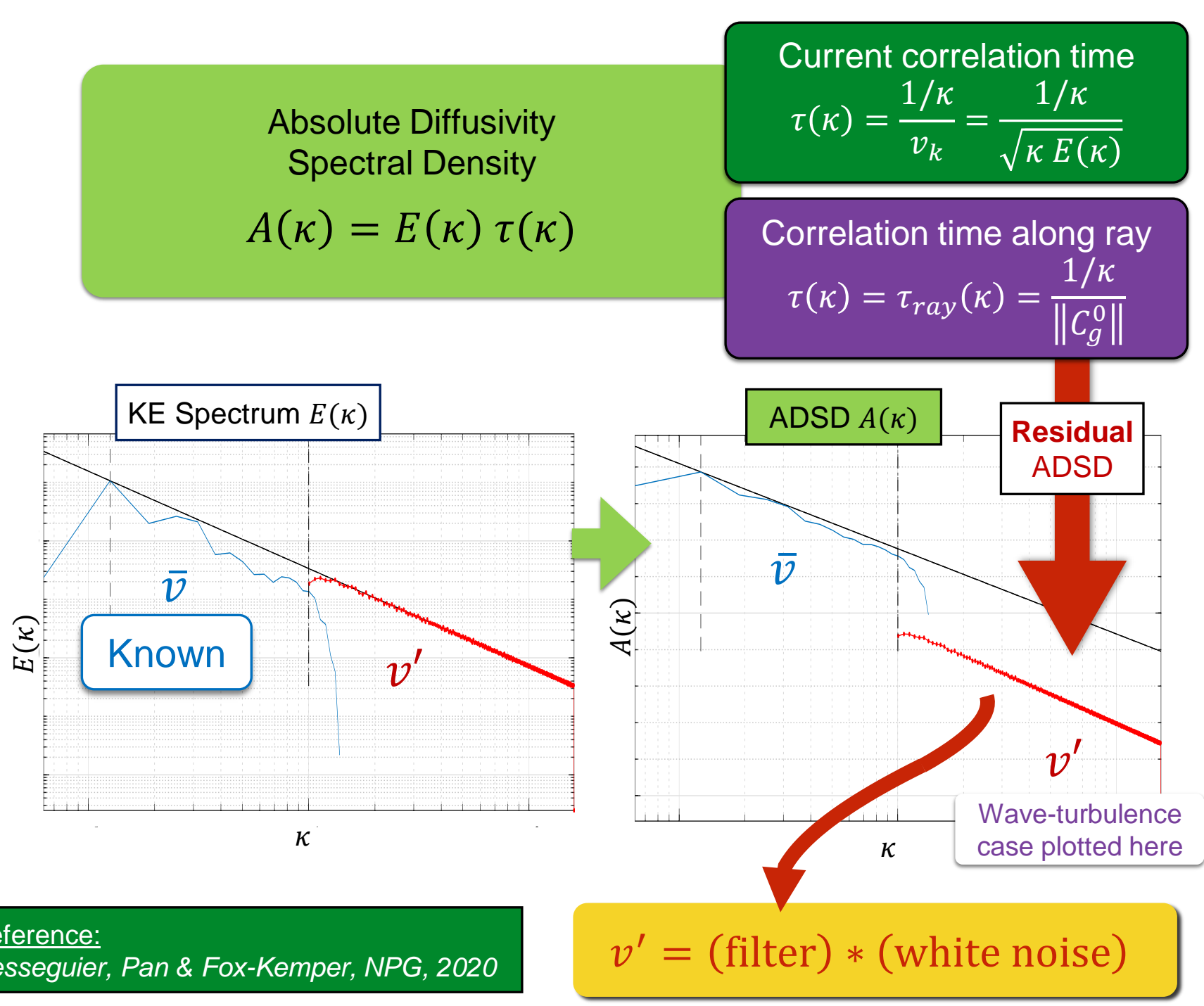

Significant wave heights, and Currents predictions, Uncertainty quantification

Parametrization of $v^{\prime}$ multiscale in space and time are also possible

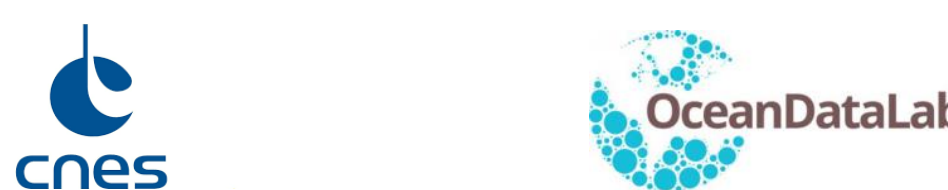

